\title{
The art of mitral valve repair: Recreating nature or learning from it?
}

\author{
Torsten Doenst, MD, PhD
}

\footnotetext{
From the Department of Cardiothoracic Surgery, Jena University Hospital, Friedrich-Schiller-University of Jena, Jena, Germany.

Disclosures: Author has nothing to disclose with regard to commercial support.

Received for publication Aug 13, 2018; accepted for publication Aug 17, 2018; available ahead of print Sept 25 , 2018.

Address for reprints: Torsten Doenst, MD, PhD, Department of Cardiothoracic Surgery, Friedrich-SchillerUniversity of Jena, Am Klinikum 1, 07747 Jena, Germany (E-mail: doenst@med.uni-jena.de).

J Thorac Cardiovasc Surg 2019;157:941-2

$0022-5223 / \$ 36.00$

Copyright (c) 2018 by The American Association for Thoracic Surgery

https://doi.org/10.1016/j.jtcvs.2018.08.017
}

Surgical repair is currently the undisputed gold standard for treatment of primary (ie, structural) mitral regurgitation. It is superior to replacement and interventional techniques and has the potential to restore normal life expectancy. ${ }^{1,2}$ However, repair techniques may be complex and often dependent on an artistic ability of the operating surgeon. ${ }^{3,4}$ This art is important because the impact on survival and symptoms is related to repair success and durability. ${ }^{5,6}$ In addition, it is not clear how many potentially repairable valves end up being replaced for their perceived high complexity. ${ }^{4,7}$ Discussions on repair techniques even sound artistic: We have to "recreate nature," perform a "physiologic repair," have to "preserve the mobility of both leaflets," or "restore normal anatomy." However, what is "natural," "physiologic," or "normal" in a complex diseased valve with large amounts of tissue, asymmetrically prolapsing segments, and annular dilatation? In addition, the majority of all valves after successful repair do not look "normal" or "physiologic" anymore. It appears that (although we can create durable repairs) we cannot recreate nature. Can we learn from it?

In this issue of the Journal, Chawla and colleagues ${ }^{7}$ address this point by describing their experimental experience with a polytetrafluoroethylene (PTFE) patch made with 4 extensions for neochords that is anchored at the base of the papillary muscle and neochords that are attached to the leaflets. They learned from nature by applying the principle that the length from the base of the papillary muscle to the chords' leaflet insertion is the same for anterior and posterior mitral leaflets. Although the initial experience in swine is promising, application in patients has several challenges.

The design is similar to the loop technique, ${ }^{8}$ in which 4 premeasured PTFE (Gore-Tex; WL Gore \& Associates, Flagstaff, Ariz) loops are tied to a pledget for anchoring at the papillary muscle. It differs in that the loop technique resuspends the anterior or posterior mitral leaflet, while the

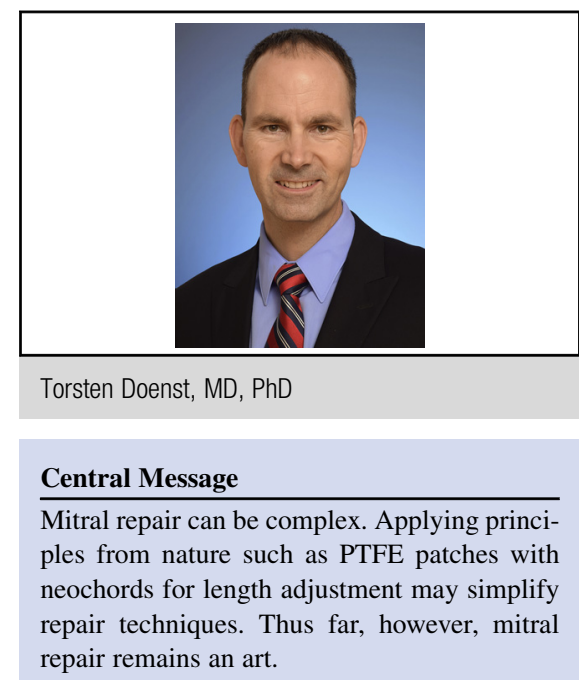

See Article page 932.

PTFE patch always supports both leaflets at the same time (if needed, 2 patches for the whole valve attached to 2 papillary muscles). Although this principle recreates the original leaflet coaptation area, it is not clear what would happen to excessive tissue present in many prolapsing valves. The loop technique allows pulling down the posterior mitral leaflet or correcting the asymmetrical prolapse (eg, a prolapsing P2-segment is significantly larger in height than P1 or P3), providing a new zone of coaptation (a posterior curtain). The PTFE patch restores original coaptation zones, but the excessive tissue may end up moving inside the ventricle, posing a significant risk of systolic anterior motion. ${ }^{9}$ This problem specifically arises if an annuloplasty ring is added, and avoiding annuloplasty may be risky because durability classically depends on it. ${ }^{10}$ Finally, the need to anchor the PTFE patch to the base of the papillary muscles may be a challenge for the less-experienced mitral surgeon.

Nevertheless, the new patch deserves its chance in clinical practice. With that step, the art of mitral valve repair receives a new tool, and by applying it, we have learned a valuable lesson from nature. Chawla and colleagues ${ }^{7}$ should be thanked for it.

\section{References}

1. Coutinho GF, Correia PM, Branco C, Antunes MJ. Long-term results of mitral valve surgery for degenerative anterior leaflet or bileaflet prolapse: analysis of negative factors for repair, early and late failures, and survival. Eur $J$ Cardiothorac Surg. 2016;50:66-74. 
2. David TE, Armstrong S, McCrindle BW, Manlhiot C. Late outcomes of mitral valve repair for mitral regurgitation due to degenerative disease. Circulation. 2013;127:1485-92

3. Chikwe J, Toyoda N, Anyanwu AC, Itagaki S, Egorova NN, Boateng P, et al. Relation of mitral valve surgery volume to repair rate, durability, and survival. J Am Coll Cardiol. April 24, 2017 [Epub ahead of print].

4. El-Eshmawi A, Castillo JG, Tang GHL, Adams DH. Developing a mitral valve center of excellence. Curr Opin Cardiol. 2018;33:155-61.

5. Lim DS, Reynolds MR, Feldman T, Kar S, Herrmann HC, Wang A, et al. Improved functional status and quality of life in prohibitive surgical risk patients with degenerative mitral regurgitation after transcatheter mitral valve repair. J Am Coll Cardiol. 2014;64:182-92.

6. Suri RM, Clavel MA, Schaff HV, Michelena HI, Huebner M, Nishimura RA, et al. Effect of recurrent mitral regurgitation following degenerative mitral valve repair: long-term analysis of competing outcomes. J Am Coll Cardiol. 2016;67: 488-98

7. Chawla S, Frater R, Cunningham M, Padala M. Performance and healing of an expanded polytetrafluoroethylene multi chordal device at 6-months after repair of mitral leaflet flail in swine. J Thorac Cardiovasc Surg. 2019;157:932-40.

8. von Oppell UO, Mohr FW. Chordal replacement for both minimally invasive and conventional mitral valve surgery using premeasured Gore-Tex loops. Ann Thorac Surg. 2000;70:2166-8.

9. Varghese R, Itagaki S, Anyanwu AC, Trigo P, Fischer G, Adams DH. Predicting systolic anterior motion after mitral valve reconstruction: using intraoperative transoesophageal echocardiography to identify those at greatest risk. Eur J Cardiothorac Surg. 2014;45:132-8.

10. Bothe W, Miller DC, Doenst T. Sizing for mitral annuloplasty: where does science stop and voodoo begin? Ann Thorac Surg. 2013;95:1475-83. 